\title{
Helping farmers with continuation planning for cost-offset community support agriculture to low-income families
}

SPECIAL ISSUE: MORE THAN VALUE\$ IN THE FOOD SYSTEM

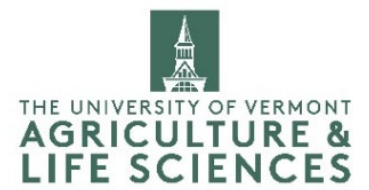

\author{
Marilyn Sitaker, ${ }^{*}$ Mackenzie McCall ${ }^{\mathrm{b}}$ \\ The Evergreen State College
}

Jane Kolodinsky, ${ }^{\mathrm{c}}$ Weiwei Wang ${ }^{\mathrm{c}}$

University of Vermont

\author{
Alice S. Ammerman, ${ }^{\mathrm{d}}$ Kristin Bulpitt ${ }^{\mathrm{d}}$ \\ University of North Carolina at Chapel Hill
}

\author{
Stephanie B. Jilcott Pitts ${ }^{\text {e }}$ \\ East Carolina University \\ Karla Hanson, ${ }^{\mathrm{f}}$ Leah C.Volpe ${ }^{\mathrm{f}}$ \\ Cornell University \\ Rebecca A. Seguin-Fowler ${ }^{g}$
Texas A\&M AgriLife Research
}

Submitted May 26, 2020 / Revised August 19, 2020 / Accepted August 20, 2020 /

Published online September 18, 2020

Citation: Sitaker, M., McCall, M., Kolodinsky, J., Wang, W., Ammerman, A. S., Bulpitt, K., Jilcott Pitts, S. B., Hanson, K., Volpe, L. C., \& Seguin-Fowler, R. A. (2020). Helping farmers with continuation planning for cost-offset community support agriculture to low-income families. Journal of Agriculture, Food Systems, and Community Development, 9(4), 93-112. https://doi.org/10.5304/jafscd.2020.094.037

Copyright (C 2020 by the Authors. Published by the Lyson Center for Civic Agriculture and Food Systems. Open access under CC-BY license.

\begin{abstract}
To improve low-income families' access to fresh local produce, some farmers offer subsidized or "cost-offset" community supported agriculture (CO-CSA) shares. We evaluated a structured
\end{abstract}

a * Corresponding author: Marilyn Sitaker, Ecological Agriculture and Food Systems, The Evergreen State College; 2700 Evergreen Parkway NW; Olympia, WA 98505 USA; +1-206-3957501; msitaker@gmail.com

b Mackenzie McCall, Ecological Agriculture and Food Systems, The Evergreen State College.

c Jane Kolodinsky, Professor; and Weiwei Wang, Research Specialist, Department of Community Development and Applied Economics, University of Vermont.

d Alice S. Ammerman, Professor, and Kristin Bulpitt, Social/Clinical Research Assistant, Department of Nutrition, Gillings School of Global Public Health and the Center for Health Promotion and Disease Prevention, University of North Carolina at Chapel Hill. planning and implementation process conducted during the final intervention year of the Farm Fresh Foods for Healthy Kids (F3HK) study, which aimed to help participating farmers $(N=12)$

e Stephanie B. Jilcott Pitts, Associate Professor, Department of Public Health, Brody School of Medicine, East Carolina University.

${ }^{\mathrm{f}}$ Karla Hanson, and Leah C. Volpe, Master of Public Health Program, Department of Population Medicine and Diagnostic Sciences, Cornell University.

g Rebecca A. Seguin-Fowler, Associate Professor, Department of Nutrition \& Food Science, Texas A\&M University System.

\section{Funding Disclosure}

This material is based upon work that is supported by the National Institute of Food and Agriculture, U.S. Department of Agriculture, under award number 2015-68001-23230. Any opinions, findings, conclusions, or recommendations expressed in this publication are those of the authors and do not necessarily reflect the views of the USDA. 
to sustain a CO-CSA program after study funding ended. The process included training webinars, planning tools to develop CO-CSA continuation funding and recruitment strategies, regional coaching teams to provide technical assistance, and periodic group conference calls to facilitate shared learning among $\mathrm{F} 3 \mathrm{HK}$ farmers. Our evaluation explored the content of farmers' CO-CSA continuation plans, their experiences during implementation, their opinions about the planning process, and their future plans regarding their CO-CSA. We found that $\mathrm{F} 3 \mathrm{HK}$ farmers used diverse methods to plan, recruit, and raise funds, with each farm adapting strategies to fit their local conditions and farm business. Many farmers found success with wordof-mouth advertising and CSA member donations. Yet lack of farm resources-time, money, and expertise-was a continual barrier to moving forward. As with full price CSAs, reciprocity was a key factor: farmers needed to consider the needs and preferences of low-income consumers, and COCSA members needed to understand their financial responsibility to the farmer. In general, F3HK farmers appreciated the continuation planning process, but expressed a desire for more technical assistance with grant writing. Farmers were committed to the success of the CO-CSA continuation planning process, and most intended to continue the CO-CSA the following year.

\section{Keywords}

Cost-Offset CSA, Entrepreneurship, Evaluation, Community Supported Agriculture, Farmer Training, Supplemental Nutrition Assistance Program, Subsidized Direct-to-Consumer

\section{Introduction}

Community supported agriculture (CSA) may help address childhood obesity by increasing consumer access to, and consumption of, fresh produce (Vasquez, Sherwood, Larson, \& Story, 2017). However, for low-income families, who are at increased risk for obesity (Larson, Story, \& Nelson, 2009; Lovasi, Hutson, Guerra, \& Neckerman, 2009; Robert \& Reither, 2004), the upfront cost of a CSA may be a barrier to participation (Freedman et al., 2016). Thus, the Farm Fresh Foods for Healthy Kids (F3HK) study was designed to test whether a subsidized, or cost-offset CSA (CO-CSA), when combined with tailored nutrition education, could increase fruit and vegetable consumption by lowincome families, while also opening a new market segment for CSA farmers (Seguin et al., 2017). Between 2016 and 2018, a CO-CSA was implemented as part of the F3HK study at 12 farms in four states: New York, North Carolina, Vermont, and Washington. The study provided farmers with new customers for the CO-CSA in the form of low-income families participating in the study, and also provided the $50 \%$ upfront subsidy for each CO-CSA share.

Previous papers from this study have described formative research and farmer experience with CO-CSA implementation (Hanson et al., 2019; McGuirt et al., 2019; Morgan et al., 2018; Sitaker, McGuirt, Wang, Kolodinsky \& Seguin, 2019; Sitaker et al., 2020). This paper describes findings from an evaluation of a structured planning and implementation process conducted during the last intervention year of the study that aimed to help F3HK farmers sustain the cost-offset portion of their CSA after study funding ended.

\section{CO-CSA Continuation Planning Process}

We held a webinar for F3HK farmers in March 2017 (Figure 1) to share current academic and market research (Galt et al., 2017; Pole \& Kumar, 2015) on low-income consumer needs and preferences regarding direct market channels, along with funding and marketing strategies gleaned from a literature review and environmental scan of CO-CSA programs (Hinrichs \& Kremer, 2002; Hoffman et al., 2012; Quandt, Dupuis, Fish \& D'Agostino, 2013). At the conclusion of the webinar, we asked farmers what information and technical support they would need to continue the CO-CSA after the study ended. Their input was used to develop a structured process to help farmers learn and practice skills for the continuing acquisition of funds and customer recruitment for the cost-offset CSA, which had previously been provided by the study.

The process included a set of tools with stepby-step instructions for developing a CO-CSA continuation plan, to be implemented in the third and final year of the F3HK intervention. The tools included ten planning worksheets on such topics as 


\section{Figure 1. CO-CSA Continuation Planning Process for F3HK Farmers}

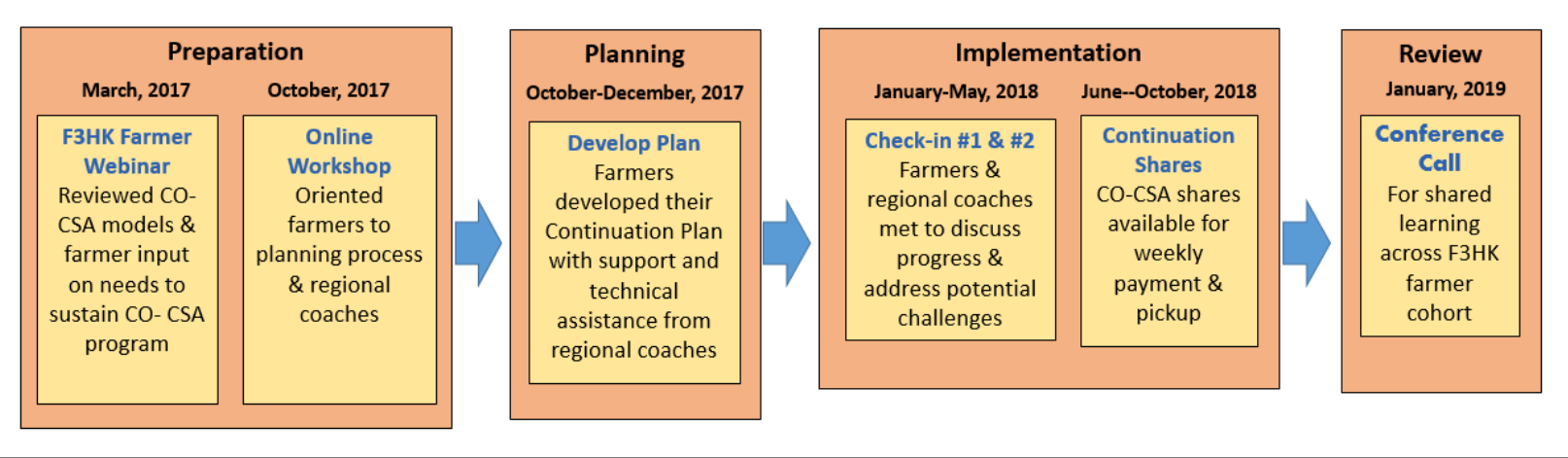

identifying potential funding strategies, setting funding targets, marketing assessment, and outreach (Sitaker, 2018). We also established and trained a regional coaching team in each state to support farmers as they planned and tested strategies over a year-long period. The teams consisted of an agricultural extension coach who helped farmers identify and access local partners and resources, and a member of the $\mathrm{F} 3 \mathrm{HK}$ research team who collected process evaluation data. Coaches met with farmers at four time-points: during the planning phase in November 2017, during two check-in meetings by phone or in person during the implementation phase, and during a postseason debriefing.

We conducted an online training workshop for farmers in October 2017 to describe the continuation planning process and introduce the regional coaching teams. The workshop included a panel discussion with three farmers who had successfully operated a CO-CSA for several years, followed by a question-and-answer session with panel members and general discussion. Over the next two months, farmers used the worksheets to develop a CO-CSA continuation plan, with assistance from their regional coaches. Farmers began implementing their plans in January 2018 and teleconferenced with their regional coaches to report their progress and receive technical assistance as needed prior to the CSA season. Farmers participated in postplanning and post-season group conference calls, which facilitated shared learning across the cohort of F3HK farmers.

Since F3HK study participants had been randomly assigned to either an intervention group or a delayed-intervention control group, only delayedintervention families received a CO-CSA supported by study funds in the final year of the intervention. Yet farmers said that some of the former F3HK participants (for whom CSA membership was no longer subsidized by research funds) still desired a CO-CSA share. These were potential customers for the continuation CO-CSA. It was up to the farmer to reach out to these families to sign them up, and farmers could also recruit additional families outside of the F3HK intervention trial if they wished. Each F3HK farmer was responsible for using strategies from their continuation plan to actively obtain funds to subsidize continuation shares.

\section{Evaluation Questions}

Our evaluation questions were based on the logic model for the continuation planning process shown in Figure 2. Moving from left to right, the logic model shows inputs and activities that lead to immediate outputs (expected preseason), followed by outcomes in the shorter and longer time frames, as well as the ultimate impacts on farm revenue, local economies, and access to locally grown produce for low-income families. The underlying theory of change (Julian, 1997) is that by providing stepwise instructions, tools, and resources, along with technical assistance and support from their learning cohort, CO-CSA study farmers would successfully plan and implement funding and marketing strategies to continue the CO-CSA when study funding ended.

As we followed farmers only during the 2018 CSA season, this evaluation focused on the outputs 


\section{Figure 2. CO-CSA Continuation Planning Logic Model}

\begin{tabular}{|c|c|c|c|c|}
\hline \multirow[t]{2}{*}{ Inputs } & Activities & Outputs & \multicolumn{2}{|c|}{ Outcomes } \\
\hline & & & Shorter Term & Longer Term \\
\hline $\begin{array}{l}2 \text { years' CO-CSA } \\
\text { experience } \\
\text { Potential CO-CSA } \\
\text { members for } \\
2018 \\
\text { Regional } \\
\text { Coaching Teams } \\
\text { Cohort of fellow } \\
\text { CO-CSA farmers } \\
\text { Planning } \\
\text { Worksheets } \\
\text { Local information } \\
\text { and resource } \\
\text { links } \\
\text { List of potential } \\
\text { local partners }\end{array}$ & $\begin{array}{l}\text { Attend CO-CSA } \\
\text { continuation } \\
\text { planning workshop } \\
\text { Develop a funding } \\
\text { and marketing plan } \\
\text { for } 2018 \\
\text { Group call to share } \\
\text { plans with other } \\
\text { F3HK farmers } \\
\text { Implement the } 2018 \\
\text { funding and } \\
\text { marketing plan } \\
\text { Debrief with coaches } \\
\text { and farmers after the } \\
2018 \text { growing season }\end{array}$ & $\begin{array}{l}\text { Completed } \\
2018 \text { CO-CSA } \\
\text { funding and } \\
\text { marketing } \\
\text { plans } \\
\text { Funding for } \\
\text { CO-CSA } \\
\text { continuation } \\
\text { New } \\
\text { partnerships } \\
\text { Strategies to } \\
\text { retain } \\
\text { existing CO- } \\
\text { CSA } \\
\text { members } \\
\text { Strategies to } \\
\text { attract new } \\
\text { members }\end{array}$ & $\begin{array}{l}\text { Farmers are able to } \\
\text { provide a CO-CSA to } \\
\text { some of the customers } \\
\text { who want it } \\
\text { Farmers are able to meet } \\
\text { needs of low-income CO- } \\
\text { CSA members } \\
\text { Increased awareness } \\
\text { about the farm's CO-CSA }\end{array}$ & $\begin{array}{l}\text { Farmers attract new low- } \\
\text { income customers } \\
\text { Farmers have sufficient } \\
\text { funding to meet } \\
\text { customer demand for } \\
\text { CO-CSA }\end{array}$ \\
\hline
\end{tabular}

a This evaluation focuses on short-term outcomes only, measured immediately after the intervention ended. This logic model also shows outcomes and impacts expected in the longer term that were not measured.

and some short-term outcomes of the continuation planning process. The questions to be answered in this evaluation were as follows:

1. What funding and outreach strategies did farmers select for their 2018 continuation plans?

2. What were farmers' experiences during implementation?

3. What did farmers perceive as their biggest successes?

4. Which aspects of the continuation planning process did farmers find useful as they created and implemented plans to continue CO-CSA on their own?

5. What are farmers' future plans regarding their CO-CSA?

\section{Methods}

The data collected during the continuation planning process included (1) farmers' continuation plans, (2) notes from two preseason check-ins, (3) notes from post-planning and post-season group calls with farmers and regional coaches, and (4) audio-recorded post-season debriefing interviews with farmers. This study was approved by the institutional review boards at Cornell University and the University of Vermont. Written consent was obtained from all subjects.

\section{Data Collection}

The research member of the regional coaching team made notes of their observations during check-in meetings to document progress in implementing funding and marketing components of each farmer's continuation plan, along with the problems and potential solutions encountered. (See Appendix B for the structured note-taking guide.) The agricultural coaching team member conducted postseason debriefing sessions, which were audiorecorded by the research team member. (See Appendix B for the debriefing guide.) Audio- 
recordings were transcribed verbatim for subsequent analysis.

\section{Analysis}

We conducted content analysis of the continuation plans, abstracting information on each farmer's planned funding and outreach strategies, partners to be engaged, and action steps to be taken, along with the timeline for completion. We also reviewed structured notes taken during preseason check-ins with the coaching team, along with notes of the farmers' comments during two group conference calls. Transcripts of the postseason debriefing sessions were imported into NVivo qualitative data analysis software (QSR International Pty Ltd., Version 11), and coded by question. The first two authors selected a subset of transcripts for open coding, and then met to discuss the coding process and emergent ideas. These discussions informed the development of a preliminary descriptive codebook reflecting the farmers' experience with CO-CSA continuation planning and implementation. We then iteratively and collaboratively revised and refined the codebooks by using it to code the remaining transcripts, discussing and then resolving any coding discrepancies. Once we reached consensus about the code definitions, we coded all interviews. Qualitative data from debriefing interviews were then analyzed by reviewing, organizing, and summarizing codes. Data from the multiple sources were then triangulated to answer each evaluation and elaboration question (see Appendix A for the sources used to answer the questions).

\section{Results}

\section{Farmer Plans and 2018 Implementation Experience} In this section, we first describe logistical and operational arrangements the farmers made regarding CO-CSA continuation shares, including how they estimated the funding targets for subsidized shares. Next, we review the farmers' plans and experience implementing various funding strategies, followed by their plans and experience implementing various strategies for outreach and retention, including their efforts to engage the support of community partners.
Description of CO-CS A Continuation Logistics In 2018, farms still had active F3HK study participants (on average, about seven per farm) who were subject to study protocols regarding CO-CSA operations, described in Seguin et al., 2017). Thus, for convenience, F3HK farms applied most of the F3HK study logistics to the continuation shares. For example, they allowed continuation members to pay the CO-CSA balance in weekly installments at the time of share pick-up. They also asked continuation share members to give them a refundable preseason deposit, equivalent to two weeks of installment payments, to cover the cost of any missed pick-ups. Farms used the same pick-up locations for continuation share members as for their traditional CSA members and F3HK study participants. For example, four held pick-ups onsite, three at farmers markets, and three at community locations. Four farms had multiple pick-up sites.

Most farms used the F3HK income eligibility guidelines for new continuation share subscribers (income $\leq 185 \%$ of the federal poverty level), although one farm planned to accept slightly higher incomes for families that appeared to be struggling financially. As in the F3HK study, farmers planned to accept Supplemental Nutrition Assistance Program (SNAP) payments through electronic benefit transfer (EBT) from continuation share subscribers; seven farms explicitly planned to encourage SNAP beneficiaries to pay for three weeks' payments using one SNAP EBT transaction (allowable under SNAP rules for shares picked up within 14 days).

Farms based the estimated number of continuation shares for 2018 on the number of former F3HK participants they thought would sign up; this ranged from three to 20 participants, 11 on average. Ten farms planned to continue to offer a $50 \%$ offset as in the $\mathrm{F} 3 \mathrm{HK}$ intervention, but one farm planned to offer an offset of $25 \%$, and another of $33 \%$. Farmers used the estimated number of continuation share subscribers, percentage of price to offset, and share prices to calculate the funds needed, which ranged from US $\$ 650$ to US $\$ 4,800$, $\mathrm{US} \$ 2,468$ on average.

Continuation shares were offered on a firstcome, first-served basis, with returning F3HK 
participants receiving priority. The number of available continuation shares depended on the amount of funds raised. If there were more interested CO-CSA applicants than available shares, farmers communicated that they would either start a waiting list or offer their market-priced shares in a smaller size or payable in installments. Referrals to other CO-CSA farms or to other community resources such as a food bank were options also mentioned.

\section{Fundraising Strategies}

Table 1 displays each farm's experience with various funding strategies, indicating those originally planned, those planned but later dropped, and those not originally planned but adopted later.

Table 1. Fresh Foods for Healthy Kids (F3HK) Farmers' Experiences with Strategies to Fund Cost-Offset (CO) Community Supported Agriculture (CSA) Continuation Shares

\begin{tabular}{|c|c|c|c|c|c|}
\hline $\begin{array}{l}\text { Farm } \\
\text { ID }\end{array}$ & Member Donations & Community Donations & Grants & $\begin{array}{l}\text { Fundraising Events or } \\
\text { Merchandising }\end{array}$ & Self-Funding by Farm \\
\hline 1 & Dropped & & & $\begin{array}{l}\text { Planned but } \\
\text { changed: Raised } \\
\text { US } \$ 5,000 \text { from } \\
\text { specialty drinks }\end{array}$ & $\begin{array}{l}\text { Adopted later: Would } \\
\text { self-fund if needed }\end{array}$ \\
\hline 2 & $\begin{array}{l}\text { Dropped: Sliding fee } \\
\text { scale }\end{array}$ & & $\begin{array}{l}\text { Dropped: Writing with } \\
\text { nonprofit }\end{array}$ & & $\begin{array}{l}\text { Adopted later: Would } \\
\text { self-fund, but decided } \\
\text { not to offer shares }\end{array}$ \\
\hline 3 & $\begin{array}{l}\text { Planned: Allow early- } \\
\text { bird discount }\end{array}$ & $\begin{array}{l}\text { Dropped: Church as } \\
\text { partner }\end{array}$ & & & $\begin{array}{l}\text { Adopted later: Gave } \\
\text { produce of equal } \\
\text { value to those who } \\
\text { donated }\end{array}$ \\
\hline 4 & $\begin{array}{l}\text { Planned: Raised } \\
\text { funds for one CO-CSA }\end{array}$ & & & & $\begin{array}{l}\text { Adopted later: Would } \\
\text { self-fund if needed }\end{array}$ \\
\hline 5 & $\begin{array}{l}\text { Planned: Raised } \\
\text { US } \$ 500 \text { from CSA } \\
\text { members }\end{array}$ & $\begin{array}{l}\text { Planned: Raised } \\
\text { US } \$ 500 \text { from church } \\
\text { members }\end{array}$ & & & $\begin{array}{l}\text { Adopted later: Farm } \\
\text { made up remainder } \\
\text { of CO contributions }\end{array}$ \\
\hline 6 & $\begin{array}{l}\text { Planned: US\$1,000 } \\
\text { from donations of } \\
\text { early-bird discount }\end{array}$ & $\begin{array}{l}\text { Dropped: Appeals at } \\
\text { co-op and via non- } \\
\text { profit }\end{array}$ & & & \\
\hline 7 & Dropped & $\begin{array}{l}\text { Dropped: Appeals to } \\
\text { local banks }\end{array}$ & $\begin{array}{l}\text { Dropped: Grants } \\
\text { from local banks }\end{array}$ & $\begin{array}{l}\text { Dropped: Community } \\
\text { fundraiser event }\end{array}$ & \\
\hline 8 & & $\begin{array}{l}\text { Planned: Two } \\
\text { generous donations }\end{array}$ & $\begin{array}{l}\text { Planned: Nonprofit } \\
\text { gave } 25 \% \text { CO match }\end{array}$ & $\begin{array}{l}\text { Planned: } 25 \% \text { CO } \\
\text { match when partners } \\
\text { helped organize } \\
\text { event }\end{array}$ & \\
\hline 9 & & & $\begin{array}{l}\text { Planned: Nonprofit } \\
\text { gave } 25 \% \text { CO match }\end{array}$ & & $\begin{array}{l}\text { Adopted later: } \\
\text { Internal budgeting, } \\
\text { based on available } \\
\text { funds }\end{array}$ \\
\hline 10 & $\begin{array}{l}\text { Planned: Raised } \\
\text { funds for one CO-CSA } \\
\text { share }\end{array}$ & $\begin{array}{l}\text { Dropped: Food bank } \\
\text { as partners }\end{array}$ & $\begin{array}{l}\text { Adopted later: Grant } \\
\text { funding CO shares }\end{array}$ & & \\
\hline 11 & $\begin{array}{l}\text { Adopted later: } \\
\text { Raised US } \$ 200 \text { from } \\
\text { member }\end{array}$ & & $\begin{array}{l}\text { Adopted later: Grant } \\
\text { funding } \mathrm{CO} \text { shares }\end{array}$ & $\begin{array}{l}\text { Dropped: T-Shirt } \\
\text { merchandise sales }\end{array}$ & $\begin{array}{l}\text { Adopted later: Would } \\
\text { self-fund if needed }\end{array}$ \\
\hline 12 & & & $\begin{array}{l}\text { Adopted later: Grant } \\
\text { funding }\end{array}$ & & $\begin{array}{l}\text { Dropped: Self-fund } \\
\text { one CO-CSA }\end{array}$ \\
\hline
\end{tabular}

Note: Shaded cells indicate strategies that yielded funding for continuation shares. 
Shaded cells indicate strategies that yielded results that were used to fund the continuation CO-CSA. Most farmers initially planned to pursue two or more strategies, though many altered, dropped or added strategies during the preseason period. The most frequently planned fundraising strategy for 2018 was soliciting donations from CSA members and the wider community, followed by grant-writing, hosting fundraising events, selling merchandise, and self-funding.

Donations: Eight farms planned to solicit donations from current and former CSA members, using direct email appeals, notices on social media and farm websites, and donation jars at the farm stand. Two farms planned to start a sliding-fee scale program, while two others gave members the option to donate their early sign-up discounts to a $\mathrm{CO}$ fund. To enhance their donation requests, two farms planned to feature quotes from CO-CSA members. Another farmer planned to show an explicit breakdown of farm expenses, believing that this would encourage members to increase their donations once they gained a better understanding of production costs.

Prior to the season, a ninth farm decided to adopt a donation strategy, but three farms abandoned their original plans regarding member donations. Overall, six farmers reported moderate success, with individual CSA member donations ranging from a few hundred dollars to US $\$ 1,000$.

Community Donations: Six farmers planned to solicit donations from the wider community and ask community partners to either donate themselves or to pass along donation requests to their constituents. Potential partners included churches, nonprofit organizations, schools, co-ops, banks, businesses, and food banks. Prior to the season, however, farmers had difficulty finding time to cultivate partner relationships. In all, four decided not to continue with this strategy. Two farms found success, with one receiving donations from two generous donors that covered all continuation shares, and another receiving US $\$ 500$ from a local church congregation.

Fundraising: Four farms had originally intended to hold community fundraising events or merchandise sales; one decided to postpone its event until 2019 and another farm dropped its merchandising plans to focus on CSA member donations instead. One farm found success with a strong community partner that helped it organize a successful fundraiser. Another scaled back plans of hosting an on-farm barbecue in favor of offering to donate a portion of each farm-brewed beverage sold to support a continuation share, a strategy that garnered US $\$ 5,000$ for its CO-CSA fund.

Grants: Four farms initially planned to subsidize shares through grant writing. At check-in, two reported that they were unable to find suitable funding opportunities and needed help with grant writing, as they did not have sufficient time or skills. With assistance from the regional coaches, three additional farms in Washington received a grant from the state department of agriculture to fund as many former F3HK participants as enrolled, up to US $\$ 5,843$ per farm. These farms appreciated the funding but found it burdensome to negotiate contracts, record transactions, and prepare invoices as required by the funder.

Self-funding: In all, eight farms considered self-funding continuation shares, with most using it as a backup if other strategies were unproductive. One farm supplemented member and community donations to fund the CO-CSA, while another provided produce of equal value to CSA members' donations. Additionally, one farm made up the balance from its "internal budget, based on available funds."

Two farms used surplus funds from the previous year to fund some or all of the continuation shares, while another decided not to fund any continuation shares at all when no funds were raised.

In summary, soliciting member donations was a popular strategy that was easy to implement and yielded modest amounts for six farmers. Direct community appeals and fundraising events were more challenging, due to the time and effort required to cultivate community partnerships. Nevertheless, these efforts yielded substantial sums for four farms. Seven farms attempted to obtain grants, although this required skill and time investment; for three, this was a very successful strategy.

Farmers who were initially ambitious about grant writing, event planning, or working with community partners during the planning stage often had to revise or scale back their plans due to 
pressing farm responsibilities. Even for strategies that were fairly easy to incorporate, however, fundraising was challenging because it was difficult to know how much would be raised and when funds would be received. As one farmer said,

[It] took a while to figure out what we were going to do because of ... not knowing if we'd be able to accept EBT next year and so then not knowing how much money we were going to be trying to raise. (Farm 7)

For wider community fundraising campaigns, social media was a simple yet effective way for farmers to reach more people and increase the number and amount of contributions. Donations were boosted by featuring stories and quotes from both subsidized and market-rate subscribers, and by placing a donation option on the online sign-up form.

Farms unable to raise sufficient funds to meet the demand for continuation shares sometimes opted to reduce the number of continuation shares offered, putting potential customers on a waiting list. Others attempted to make full-cost CSA shares more accessible by reducing other barriers for lowincome families. For example, one farm decided to forego plans to institute a sliding-fee scale and instead offered a smaller deposit and weekly payment option to low-income members. Another offered half-shares at market rate to low-income members. A third farm lowered the cost offset fee to $10 \%$, and covered it itself as a farm expense.

\section{Outreach and Retention Strategies}

For the 2018 season, seven farmers planned to contact former F3HK study participants before trying to recruit new customers for the continuation CO-CSA. Most took an individual approach, sending emails to each former F3HK participant on their membership roster.

Nine farms had formal plans to recruit new continuation CO-CSA members. Most began by notifying their current and former CSA members, encouraging them to tell friends and neighbors about CO-CSA continuation shares. As one farmer noted, former F3HK participants in particular were "great spokespersons for the CO-
CSA program." This word-of-mouth approach turned out to be the most effective and widely used outreach strategy; it was what farmers fell back on when other forms of outreach failed. A few farms also planned active outreach at community events, churches, farmers markets, and local nonprofits. For example, one farm successfully hosted meet-and-greet demonstrations, "tabling" at a community event to speak about its CO-CSA and provide sample vegetables.

Farmers also planned to market the continuation CO-CSA on social media and the farm website. Seven intended to distribute flyers (including in Spanish for two farms) with the help of outreach partners at food banks, Head Start programs, Women, Infants and Children (WIC) programs, and SNAP Education programs, county extension offices, food co-ops, YMCAs, and local health departments. One farm reported that mentioning installment payment options in its marketing materials elicited more responses, while another noted that accepting SNAP, WIC, Farmers' Market Nutrition Program coupons, and flexible payments seemed to bring in more customers.

During postseason debriefings, two farms reported successful recruitment as a result of partner collaboration; however, five others noted little progress, mainly because they lacked the time to cultivate the partner relationships needed to support outreach. In general, farmers said that recruitment was challenging, noting that it was difficult to find "the right people that are gonna benefit from the program..." (Farm 1). Another farmer noted,

Just to explain the concept, was a hard thing, and then we realized you can't expect someone who's low income to pay in advance. They just can't do it, so then we went to, "OK, well then, if they pay weekly." ... We worked pretty hard at it and it was really hard to recruit people. (Farm 4)

Recruitment was intimately tied to fundraising; several farmers decided not to conduct outreach beyond the former F3HK participants they already had, explaining, "I would have to fundraise more" if additional members were recruited (Farm 8). Thus, the number of CO-CSA continuation shares 
sold was dependent on the amount raised, and contributions tended to come in slowly. Farmers were sometimes uncertain about how many COCSA shares they would be able to offer until the last moment, as they waited for donation pledges to arrive. There were eight farmers who chose not to seek new CO-CSA members, and instead emphasized flexible payments and EBT acceptance on market-rate CSAs as options for low-income subscribers.

\section{Farmer satisfaction with continuation planning process} Most farmers said that F3HK study participation was beneficial (Sitaker et al., 2020); many also said the continuation planning process was useful, as it helped them set goals and determine a course of action:

I thought the [continuation planning] session that I had with [regional coaches]...last year, that was helpful, kind of to get things moving forward, thinking about the future. ... And, [the regional coaches] got a list of resources that I have hiding away someplace that I know will be useful at some point. (Farm 12)

I think having a continuation plan, like fundraising goals and all of that in place, is really helpful. And just the whole process over the last few years of seeing what can happen and strategizing around how to make it happen. I don't think it's something [the farm] would have just done on its own. (Farm 11)

Additionally, the process encouraged them to reach out to new community members:

I think it was a great program. We really appreciated being a part of it and involved-we sure learned a lot. It helped us to get to know new community members that we wouldn't have otherwise met. (Farm 2)

The planning process was perceived as less impactful by farmers who were already experienced in CO-CSA management, fundraising, and customer outreach. Still, one such farmer said that the process helped with "identifying people who can use the program" (Farm 9). This farmer noted that the F3HK study participants constituted a small portion of their membership, which included fullpay members and subsidized members who were not part of the study.

Additionally, conversations with regional coaches during the preseason check-ins were helpful for some farms:

It's very helpful to have someone to talk it out with and, someone to ask questions and someone, I feel like in my discussion with you I do a fair bit of complaining about the things that are hard. And that's also helpful because sometimes it feels especially frustrating when I'm trying to collect cash this far out. Like, why am I doing this? But to have someone to chat about it with is helpful. (Farm 8)

Farms that received grants appreciated that regional coaches provided technical assistance with reports to funders:

I just needed to report monthly to [funder], basically that time sheet that [the regional coach] had created, that we signed in the end. That was critical that [the regional coach] did that. (Farm 12)

Some farmers found that periodic conference calls with other F3HK farmers engaged in developing and implementing their CO-CSA continuation plans were helpful:

I thought it was good to hear, to you know, be on the call just to hear a little bit from some of the other farmers across the country. I just thought that was interesting. (Farm 12)

When asked what additional information or assistance was needed for the continuation process, some farmers said the process adequately met their needs. However, Farm 12 said that more help identifying local funding resources and potential community partners was needed. Farm 7 said it would be helpful to have a template with language for a payment plan agreement, and also help with tracking various payment sources, 
including SNAP EBT:

At a certain point we had those payments coming in-we had Square, we had an online QuickBooks thing, we had cash, we had credit cards. It was just like seven different payment types coming in and I just couldn't keep track of it in the middle of the summer. (Farm 7)

Another farmer was able to find supplementary information on their own:

I can't say . . . that there's, there's anything that you guys could have done or shared that would have ... made anything different necessarily ... I've done a lot of my own independent research and seen some good ideas. It's a matter of finding something that works for our customers and for us. (Farm 3)

Finally, a few farmers expressed interest in learning about best practices that emerged from the study, particularly learning from other farmers:

Well, I think any sort of report that comes out of this program with best practices-I think that will be useful for future. Like let's say it's a new farm that hasn't done this before, best practices would be useful, things to consider. Having a good organization of who has paid in full and who is still paying so that you're able to capture that. And those weekly checklists for who signs in and who doesn't . . Any types of marketing campaigns that are successful like that farms have, I'd love to see how other farms market it. (Farm 2)

\section{Farmers' plans}

Nine of the twelve F3HK farms planned to continue the CO-CSA in 2019. In postseason debriefings, they described plans for fundraising, outreach, and program logistics for the upcoming year, describing successful strategies they would repeat as well as new ideas to try.

Fundraising: Five farmers mentioned specific plans to continue to solicit member donations, explaining that dedication to the CSA model seemed to motivate members to fund the CO-
CSA. Plans included following up with a church that had expressed interest, allowing members to contribute their "early-bird" discount toward a CO-CSA, offering a holiday buy-one, give-one box, and increased use of social media and other technology to make donating online easier. Three farms were planning fundraisers, such as a fermentation workshop, in collaboration with other local farms. One farm hoped to be included in a community grant application to USDA for 2019, while two others were assured of continuing Washington State Department of Agriculture (WSDA) grant funding. As of the postseason debrief, two farms (Farms 3 and 5) had already started accumulating member donations for the following season, and a third had set aside rollover funds. A fourth farm said it planned to raise a little extra to cover COCSA subscribers who drop out early.

Outreach: As of the postseason debriefings, few farmers had a formal CO-CSA marketing plan for 2019. Three farms planned to contact returning CO-CSA members and two planned outreach to SNAP recipients among current membership. Four said they would rely on word of mouth to find new subscribers, while others planned to advertise the program on farm websites and social media. One farm intended to enlist Head Start partners for help with outreach, while another planned to work with food banks and WIC offices, with help from an extension nutrition educator. Farmers also hoped to attract low-income and migrant populations by highlighting SNAP EBT acceptance and promoting culturally appropriate produce in their CO-CSA marketing materials.

Because fundraising and marketing the COCSA require significant effort on top of a farm's existing heavy workload, one farm recommended that a staff person be hired by the farm, if possible, to coordinate CO-CSA program operations.

Logistics: Farms offered several suggestions to streamline payment transactions in 2019. One farm planned to get rid of written forms and accept online payments only. Another planned to institute a policy that would allow them to retain a customer's credit card information for automatic monthly payments, with the customer's written permission. A third farm had plans to automate payment reminders: 
This year we're going to set up online, you either pay or you submit a form that goes straight into our sign-up database where it's a form that you can fill out telling me when you're going to pay things. And it's going to give me alerts like each week, if someone says they're going to pay in four installments or something, I'm going to put in there to schedule those dates and it's going to give me an alert that says Email so-and-so to tell them this is when they're going to give me their next payment. (Farm 8)

\section{Summary and Discussion}

F3HK farmers made it clear that the CO-CSA continuation process was valuable, as it prompted them to think strategically about how to continue the CO-CSA program after grant funding ended and provided tools and resources that helped them do so. They appreciated having regional coaches on hand to discuss strategies during planning and help problem-solve during implementation. Farmers valued periodic group conference calls with other F3HK famers as a way to hear about what others were doing, as well as a means to share solutions to common problems. When asked what could be improved in the process, farmers said they wanted more assistance with identifying local funding resources and potential community partners, grant-writing, and obtaining tools for tracking various payment sources, including EBT, and COCSA member agreement templates.

Most farmers planned to use two or more fundraising approaches, although many altered, dropped, or added strategies along the way. Soliciting donations from CSA members and the wider community was the most popular fundraising strategy, easy to implement and garnering modest yet reliable results. Some farmers had intended to write grants, host fundraising events, or sell merchandise, but due to lack of time and staff resorted to simpler methods of soliciting donations and self-funding the $\mathrm{CO}$ CSA. Still others decided they would not offer continuation shares, but instead would emphasize the availability of installment payment plans and SNAP EBT acceptance in their marketing materials. Three farmers received state grant funding to cover all their continuation shares, though they found reporting requirements to be burdensome. Two other farms received unusually large donations from a few generous community donors. These last two examples represented the highest amounts raised, but were not necessarily predictable approaches to fundraising.

To enroll participants in the continuation COCSA, more than half the farmers had planned to contact former F3HK study participants first, and then rely on word-of-mouth advertising to attract new customers. Word-of-mouth outreach has been described by Wholesome Wave (n.d.) as the most effective mechanism for outreach, which in addition to spreading the word about the CO-CSA builds trust and awareness among potential customers. Farmers also used social media, and hoped to cultivate relationships with community partners who would help to spread the word, although farmers had less time to do this than they had anticipated.

Strategies that required more effort over longer periods, such as community appeals, marketing campaigns, fundraising events, and grant writing, were harder to execute. Similarly, strategies that depended on community partnerships experienced setbacks when farmers found it hard to find time to cultivate these relationships. In addition to the day-to-day time demands of farming, farmers cited unexpected extreme weather events, equipment breakdowns, and staffing transitions as impediments to implementing their continuation plans.

The timing and coordination of fundraising and recruitment activities were critical, since determining how many CO-CSA shares to offer depended on the amount of funds raised. Funding sometimes came in small increments, requiring ongoing record-keeping. Farmers were often still waiting for funds to come in after the season began. Self-funding was sometimes the default solution when other funding strategies failed, although some farmers were reluctant to use it.

While farmers generally felt that the CO-CSA continuation process helped them, there were three areas where they asked for additional support: identifying specific funding opportunities, cultivating community partnerships, and developing member agreement templates to ensure that customers 
had a clear understanding of their responsibilities as CO-CSA members.

CO-CSA farmers may benefit from more information about two fundraising models that require minimal time to maintain once they are set up: sliding-fee payments and revolving loan funds. CO-CS A Continuation Planning for Farmers ${ }^{1}$ provides information to $\mathrm{F} 3 \mathrm{HK}$ farmers who wished to implement sliding-fee scale models. A sliding-fee scale, which sells shares at a variable price according to members' ability to pay (Guthman, Morris, \& Allen, 2006; Henderson \& Van En, 2007), was initially considered by two farms, who later declined to pursue it. In a revolving loan fund, fundraising covers the full cost of shares in advance of the season, and installment payments are used to replenish the fund for the following year (Wholesome Wave, n.d.). Farmers might also benefit from grant-writing workshops and technical assistance to help them prepare proposals to businesses, hospitals, and private foundations, as well as state and federal sources.

Most farmers were already aware of the local nonprofits, businesses, and public organizations who could help them with fundraising and outreach activities; in some cases, farmers had previous experience working with partners on farm and community food events. However, links to practice-based guides such as How to Start a CSA Nutrition Incentive Program (Wholesome Wave, n.d.) or Sowing the Seeds of Food Justice (Lennon, 2018) may provide additional resources to inspire farmers. For example, the latter resource manual describes the grassroots-organizing approach to outreach successfully implemented by Soul Fire Farm, as well as an in-depth discussion of the strengths and expertise that social service agencies and nonprofits can bring as outreach and fundraising partners.

Our experience aligns with that of other researchers (Guthman et al., 2006; Hinrichs \& Kremer, 2002) who report that many farmers know and understand the needs and preferences of lowincome families and have developed their own ways of accommodating this consumer group (Sitaker et al., 2020). Still, farmers experienced dropouts, late payments, and missed pickups

${ }^{1}$ http://collections.evergreen.edu/s/repository/item/6979
(Sitaker et al., 2020), and sometimes struggled with initiating "difficult conversations" with CO-CSA members about these issues. As other research affirms, customer commitment to the CSA model ensures better compliance and retention (Galt et al., 2017; Pole \& Kumar, 2015). For example, Wholesome Wave (n.d.) advises CO-CSA farmers to "enroll community members who are excited about the program" (p. 26) and have a clear understanding of their responsibilities as CSA subscribers. Our research indicates that F3HK farmers understood their responsibilities and wanted to formalize them as part of the member agreement.

Former F3HK participants entered the continuation phase with an understanding of their COCSA member responsibilities, conveyed through the F3HK study recruitment and enrollment materials' explicit expectations for members. Knowledge and skill barriers to CO-CSA retention were addressed through the skill-building nutrition classes, while interactions during pickup helped to cement the reciprocal farmer-member relationship. During the continuation phase, some F3HK farmers took additional steps to help their CO-CSA members better understand the CSA model and the challenges that CSA farmers face in general. To build on those efforts, educational materials that explain CSA concepts, in a format accessible to low-literacy populations, could be made publicly available to CO-CSA farmers who wish to tailor them to fit their own operations. How to Start a CS A Nutrition Incentive Program (Wholesome Wave, n.d.) and Sowing the Seeds of Food Justice (Lennon, 2018) contain excellent advice on how to build reciprocal relationships with low-income subscribers; additionally, local nonprofits and social services partners can be a source of advice and mutual support.

The present study provides insights into farmers' experience with a structured process to guide planning and implementation of a CO-CSA continuation plan. While executing fundraising and outreach activities was sometimes challenging due to pressing farm responsibilities, most farmers were committed to offering the CO-CSA after study funding ended. As previously reported, 
F3HK farmers were strongly motivated to ensure equitable access to the food they grow, and saw CO-CSA as a way to do this (Sitaker et al., 2020). Nevertheless, a question remains regarding the economic impact of adding a CO-CSA program to a farm business' revenue stream (Sitaker et al., 2020). This question is not addressed in either F3HK or other studies, although one economic modeling study reported on potential statewide impacts of policy support for CO CSA programs (Becot et al., 2020). Further, given the modest profit margins of small and midsized farms and the economic struggle to maintain these farm businesses, it seems unfeasible and unfair to expect farmers to shoulder the burden of addressing equity in CSA access on their own (Sitaker et al., 2020).

Fortunately, recent policy changes in SNAP rules have made it easier for recipients to use their benefits to pay for a CSA, which may be a very efficient way for most CSA farmers to increase CSA access for low-income families while having a positive impact on farm revenue. Indeed, Becot et al. (2020) found that a policy that encouraged SNAP EBT recipients to purchase a CO-CSA with their benefits could add to the state economy between US $\$ 0.70$ and US $\$ 0.90$ per dollar spent. There are also indications that third-party entities are stepping in to take on the fundraising, outreach, and coordination tasks of operating a CO-CSA, tasks that are both outside the skill set of most farmers and that are often pushed aside by singlefarm CO-CSAs when farm duties take precedence. Cohen and Derryck (2011) were among the first to conduct an in-depth case study of a CO-CSA operated by a nonprofit food hub, while Abbott (2014) and Hoffman and her colleagues (2012) evaluated CO-CSAs operated by a food bank and a nonprofit food system organization, respectively. It would be instructive to examine observational data from a cross-section of CO-CSAs operated by single farms and third-party entities in order to gain insight into the effectiveness of various organizational models, specifically regarding effects on farm businesses and on food access and dietary quality for low-income families.

\section{Conclusions}

This paper describes the experiences of farmers wishing to continue a CO-CSA program previously funded by a research study (Seguin et al., 2017). Farmers used many methods to plan and recruit, and to raise funds. Most found that soliciting donations from CSA members and word-of-mouth advertising were easy-to-manage approaches that yielded modest results. However, one size did not fit all; each farm had to adapt potential strategies to fit its local conditions and farm business. Furthermore, for most strategies resource constraints were a continual barrier to moving ahead. For example, eight of the 12 farmers had planned to ask community partners for help with fundraising and outreach, but found that the demands of farming often made it hard to find time to develop necessary relationships. There were surprises, such as the three farmers who had not planned to seek grant funding but then found a funder willing to subsidize all their cost-offset shares. And some found that planning, while important, did not predict future success. As noted in previous studies (Galt et al., 2017; Pole \& Kumar, 2015; Sitaker et al., 2019; Sitaker et al., 2020), farmers recognized that finding the "right" customer was a prerequisite to success. Farmers needed to consider the needs and preferences of low-income consumers, and COCSA members needed to understand that CSA entails certain responsibilities.

The F3HK farmers were highly committed to the CO-CSA continuation planning process. While some were not able to implement all the fundraising strategies they planned or to gain traction on developing community partnerships, continuation planning prompted them to articulate their intentions and lay the groundwork for actions they could complete over the following seasons. For many, CO-CSA continues to be a model they want to support, as shown by the high proportion of F3HK farmers who planned to continue their COCSA program after study funding ended. Organizations hoping to increase low-income consumers' access to locally grown produce through a COCSA might look to the findings of this study to assist farmers in their communities. 


\section{Acknowledgments}

We would like to acknowledge the contributions and efforts of our colleague Olivia Chitwood, as well as all extension, farmer, agricultural coaches, and educator partners who have contributed their time and expertise to the Farm Fresh Foods for Healthy Kids study.

\section{References}

Abbott, C. (2014). Evaluation of the Food Bank of Delaware community supported agriculture program (Master's thesis) University of Delaware, Newark, Delaware. Retrieved from http://udspace.udel.edu/handle/19716/15588

Becot, F. A., Sitaker, M., Kolodinsky, J. M., Morgan, E. H., Wang, W., Garner, J., ... \& Seguin, R. A. (2020). Can a shift in the purchase of local foods by Supplemental Nutrition Assistance Program (SNAP) recipients impact the local economy? Renewable Agriculture and Food Systems, 35(1), 90-101. https://doi.org/10.1017/S1742170518000327

Cohen, N., \& Derryck, D. (2011). Corbin Hill Road Farm Share: A hybrid food value chain in practice. Journal of Agriculture, Food Systems, and Community Development, 1(4), 85-100. https://doi.org/10.5304/jafscd.2011.014.011

Freedman, D. A., Vaudrin, N., Schneider, C., Trapl, E., Ohri-Vachaspati, P., Taggart, M., ... \& Flocke, S. (2016). Systematic review of factors influencing farmers' market use overall and among low-income populations. Journal of the Academy of Nutrition \& Dietetics, 116(7), 1136-1155. https://doi.org/10.1016/j.jand.2016.02.010

Galt, R. E., Bradley, K., Christensen, L., Fake, C., Munden-Dixon, K., Simpson, N., ... \& Kim, J. V. S. (2017). What difference does income make for community supported agriculture (CSA) members in California? Comparing lower-income and higher-income households. Agriculture and Human Values, 34(2), 435-452. https://doi.org/10.1007/s10460-016-9724-1

Guthman, J., Morris, A. W., \& Allen, P. (2006). Squaring farm security and food security in two types of alternative food institutions. Rural Sociology, 71(4), 662-684. https://doi.org/10.1526/003601106781262034

Hanson, K. L., Garner, J., Connor, L. M., Jilcott Pitts, S. B., McGuirt, J., Harris, R., ... \& Seguin, R. A. (2019). Fruit and vegetable preferences and practices may hinder participation in community supported agriculture among lowincome rural families. Journal of Nutrition Education and Behavior, 51(1), 57-67. https://doi.org/10.1016/i.jneb.2018.08.006

Henderson, E., \& Van En, R. (2007). Sharing the harvest: A citizen's guide to community supported agriculture (Rev. ed.). White River Junction, VT: Chelsea Green.

Hinrichs, C., \& Kremer, K. S. (2002). Social inclusion in a Midwest local food system project. Journal of Poverty, 6(1), 65-90. https://doi.org/10.1300/J134v06n01_04

Hoffman, J. A., Agrawal, T., Wirth, C., Watts, C., Adeduntan, G., Myles, L., \& Castaneda-Sceppa, C. (2012). Farm to family: Increasing access to affordable fruits and vegetables among urban Head Start families. Journal of Hunger \& Environmental Nutrition, 7(2-3), 165-177. https://doi.org/10.1080/19320248.2012.703522

Julian, D. (1997). The utilization of the logic model as a system level planning and evaluation device. Evaluation and Program Planning, 20(3), 251-257. https://doi.org/10.1016/S0149-7189(97)00002-5

Larson, N. I., Story, M. T., \& Nelson, M. C. (2009). Neighborhood environments: Disparities in access to healthy foods in the U.S. American Journal of Preventive Medicine, 36(1), 74-81. https://doi.org/10.1016/j.amepre.2008.09.025

Lennon, M. (2018). Sowing the seeds of food justice: A guide for farmers who want to supply low income communities while maintaining financial sustainability. College Park, MD: U.S. Department of Agriculture, Sustainable Agriculture Research and Education Coalition. https://drive.google.com/file/d/1StbPzR-ZGli8q2bUIjBEEU3sHobo0q9r/view

Lovasi, G. S., Hutson, M. A., Guerra, M., \& Neckerman, K. M. (2009). Built environments and obesity in disadvantaged populations. Epidemiologic Reviews, 31(1), 7-20. https://doi.org/10.1093/epirev/mxp005

McGuirt, J., Sitaker, M., Jilcott Pitts, S., Ammerman, A., Kolodinsky, J., \& Seguin-Fowler, R. (2019). A mixed-methods examination of the geospatial and sociodemographic context of a direct-to-consumer food system innovation. Journal of Agriculture, Food Systems, and Community Development, 9(1), 159-177. https://doi.org/10.5304/jafscd.2019.091.038

Morgan, E., Severs, M., Hanson, K., McGuirt, J., Becot, F., Wang, W., . . \& Seguin, R. (2018). Gaining and maintaining a competitive edge: Evidence from CSA members and farmers on local food marketing strategies. Sustainability, 10(7), 2177. https://doi.org/10.3390/su10072177 
Pole, A., \& Kumar, A. (2015). Segmenting CSA members by motivation: Anything but two peas in a pod. British Food Journal, 117(5), 1488-1505. https://doi.org/10.1108/BFJ-12-2014-0405

Quandt, S. A., Dupuis, J., Fish, C., \& D’Agostino, R. B. (2013). Feasibility of using a community supported agriculture program to improve fruit and vegetable inventories and consumption in an underresourced urban community. Preventing Chronic Disease, 10, 130053. https://doi.org/10.5888/pcd10.130053

Robert, S. A., \& Reither, E. N. (2004). A multilevel analysis of race, community disadvantage, and body mass index among adults in the US. Social Science \& Medicine, 59(12), 2421-2434. https://doi.org/10.1016/j.socscimed.2004.03.034

Seguin, R. A., Ammerman, A. S., Hanson, K. L., Kolodinsky, J., Jilcott Pitts, S. B., \& Sitaker, M. (2017). Farm Fresh Foods for Healthy Kids: Innovative cost-offset community supported agriculture intervention to prevent childhood obesity and strengthen local agricultural economies. Journal of Nutrition Education and Behavior, 49(7, Suppl. 1), S120. https://doi.org/10.1016/j.jneb.2017.05.108

Sitaker, M. (2018). Cost-offset CS A continuation planning for farmers: A guide for regional coaches. Ithaca, NY: Cornell University, Division of Nutritional Sciences. Retrieved from http://collections.evergreen.edu/s/repository/item/6979

Sitaker, M., McGuirt, J. T., Wang, W., Kolodinsky, J., \& Seguin, R. A. (2019). Spatial considerations for implementing two direct-to-consumer food models in two states. Sustainability, 11(7), 2081. https://doi.org/10.3390/su11072081

Sitaker, M., Morgan, E. H., McCall, M., Wang, W., McGuirt, J. T., Kolodinsky, J., . . \& Seguin, R. A. (2020). Balancing social values with economic realities: Farmer experience with cost-offset community supported agriculture. Journal of Agriculture, Food Systems, and Community Development. Advance online publication. https://doi.org/10.5304/jafscd.2020.094.004

Vasquez, A., Sherwood, N. E., Larson, N., \& Story, M. (2017). Community supported agriculture as a dietary and health improvement strategy: A narrative review. Journal of the Academy of Nutrition and Dietetics, 117(1), P83-P94. https://doi.org/10.1016/j.jand.2016.09.029

Wholesome Wave. (n.d.) How to start a CSA nutrition incentive program: A toolkit for Wholesome Wave's National Nutrition Incentive Network. Hard copy in possession of corresponding author. 


\section{Appendix A. Data Sources to Address Each Evaluation Question}

\begin{tabular}{|c|c|c|c|c|c|}
\hline Evaluation Questions & $\begin{array}{l}\text { Pre-planning } \\
\text { Webinar }\end{array}$ & $\begin{array}{l}\text { Farmers' } \\
\text { Plans }\end{array}$ & Check-Ins & Debrief & $\begin{array}{c}\text { Conference } \\
\text { Calls }\end{array}$ \\
\hline $\begin{array}{l}\text { 1. What strategies did farmers include in their } \\
\text { Continuation Plans? }\end{array}$ & & $X$ & & & \\
\hline $\begin{array}{l}\text { 2. What was farmers' experience during } \\
\text { implementation? }\end{array}$ & & & $X$ & $X$ & $X$ \\
\hline $\begin{array}{l}\text { 3. What did farmers perceive to be their } \\
\text { biggest Continuation Plan successes? }\end{array}$ & & & & $X$ & $X$ \\
\hline $\begin{array}{l}\text { 4. Did the Continuation Planning process meet } \\
\text { farmers' needs? }\end{array}$ & $X$ & & & $x$ & $x$ \\
\hline $\begin{array}{l}\text { 5. What are farmers' future plans regarding } \\
\text { their CO-CSA? }\end{array}$ & & & & $x$ & $x$ \\
\hline
\end{tabular}




\section{Appendix B. Evaluation Materials}

The Research member of the coaching team will be responsible for collecting evaluation data at four time points between October 2017 and October 2018: (1) Post-Planning Observations; (2) Notes from two check-in conversations with each farmer; and (3) Audio files and notes from a post-season debriefing session with each farmer.

\section{POST-PLANNING SESSION OBSERVATIONS:}

Instructions: After you have held the planning session (sometime between October and late November 2017), use the form below to record your observations. Print and complete one form per farmer. The coaching team should send a copy of all Post Planning session observation forms to Marilyn Sitaker, and keep a copy for themselves.

Farm ID\#: Name of Researcher: Date:

1. What are your overall impressions of your planning session with this farmer?

2. Please record the duration of the planning session: hours and minutes

3. What aspect of planning seemed to resonate most with the farmer?

4. What aspects of planning seemed to resonate least with the farmer?

5. Were there specific worksheets they seemed to be particularly interested in? If yes, what were they?

6. Were there any worksheets that the farmer seemed to have difficulty with? If yes, what were they?

7. Were there any planning aspects the farmer requested, that were not covered in the CO-CSA planning process?

8. Do you have any other impressions you would like to share? 


\section{FARMER CHECK-IN SHEET}

Instructions: Coaches should schedule two check-ins per farm, either in person or by phone, to take place between January and March 2018. Make sure to have a copy of the farmer's plan with you, so you can refer to it during the check-in. At this meeting, ask the following questions about progress toward completing activities under the CO-CSA Funding and Marketing components of the Plan, using the forms below to record your notes and observations. The coaching team should send a copy of both check-in forms for each farmer to Marilyn Sitaker, and keep a copy for themselves.

Farm ID\#: Name of Researcher: Date:

\section{CO-CSA FUNDING COMPONENT}

1. Have you worked on any activities for this component? [Use farmer's plan to probe each activity]

a. (If No), Why not? (record answer)

b. (If yes): Please list the activities have you worked on for this component (record name of each activity):
i.
ii.
iii.
iv.
v.

2. What specific actions have you taken for:
a. [Activity i]
b. [Activity ii]
c. [Activity iii]
d. [Activity iv]
e. [Activity v]

3. Record brief notes on problem-solving discussions, and decisions reached regarding modifications to activities for this component:

4. Any additional observations about implementation of CO-CSA Funding plans? 


\section{CO-CSA MARKETING COMPONENT}

5. Have you worked on any activities for this component? [Use farmer's plan to probe each activity]

a. (If No) Why not? (record answer)

b. (If yes) Please list the activities have you worked on for this component? (record name of each activity):
i.
ii.
iii.
iv.
v.

6. What specific actions have you taken for:
a. [Activity i]
b. [Activity ii]
c. [Activity iii]
d. [Activity iv]

\section{POST-SEASON DEBRIEFING SESSION WITH FARMER}

Instructions: Coaches should schedule a final debriefing session with each farmer, either in person or by phone, to take place in October 2018. Make sure to have a copy of the farmer's plan with you, so you can refer to it during the check-in. At this meeting, ask the following questions about the CO-CSA Funding and Marketing components of the Plan, using the forms below to record your notes and observations. The session will be audio recorded, and the research member of the coaching team will take notes. The researcher should upload audio file to a secure location on Cornell Box, and send a copy of the Final Debriefing notes for each farmer to Marilyn Sitaker.

Farm ID\#: Name of Researcher: Date:

1. In general, what was your experience with implementing your Continuation Plan in 2018 ? 
2. Specifically, tell me how implementation of your plans went this season for:
a. funding the CO-CSA?
b. CO-CSA logistics (if applicable)?
c. CO-CSA outreach (if applicable)?

3. Regarding implementing your plan, what were your biggest successes?
a. What factors (facilitators) contributed to the success you mentioned above?
b. What factors (barriers) got in the way of implementation?

4. What do you think were your biggest challenges with implementing your plan?

5. What information or assistance would have helped you with Continuation Planning during the 2018 season?
a. Do you plan to continue the CO-CSA next season (2019)?
b. If yes, what funding, logistical or outreach activities will you do to support your CO-CSA?

6. Are there any other comments you'd like to share about your experience with Continuation Planning? 